\title{
Accurate and Sensitive Quantification of Soy Proteins in Raw and Processed Food by Sandwich ELISA ${ }^{i}$
}

\author{
Markus Lacorn*, Tina Dubois, Susanne Siebeneicher, Thomas Weiss \\ R-Biopharm AG, Germany
}

Copyright $\bigcirc 2016$ by authors, all rights reserved. Authors agree that this article remains permanently open access under the terms of the Creative Commons Attribution License 4.0 International License

\begin{abstract}
Soy belongs to the so called "Big 8" allergens and following food labeling directives of many different countries soy has to be labeled as ingredient if used in food. Allergen labeling statements enable sensitized patients to avoid the intake of food containing soy. The major allergenic proteins in soy are Glycinin (Gly $\mathrm{m} \mathrm{6}$ ) and B-Conglycinin (Gly $\mathrm{m}$ 5). The sandwich ELISA RIDASCREEN ${ }^{\mathbb{R}}$ FAST Soya quantifies these two proteins in unprocessed as well as in processed food. The following performance characteristics were validated: Selectivity, limit of detection, limit of quantification, precision, recovery, and robustness. First results from proficiency test rounds verified these validation results. In summary, the assay shows high precision and very good recoveries for all different types of samples. It is robust against normal occurring variation within a laboratory. Compared to other test-kits on the market, this ELISA is suitable for the recognition of unheated to strongly heated soy proteins in various foods. Therefore the test can be used for most samples on the market that contain intact soy protein.
\end{abstract}

Keywords Allergy, Soy, ELISA, Validation, Processed Food, Proficiency Test

\section{Introduction}

Food allergy is one of the most important public health concerns with only a small number of eight major foods accounting for $90 \%$ of all reactions in sensitized consumers: milk, egg, fish, crustacean shellfish, tree nuts, peanut, wheat, and soybean [1]. These important allergens have to be labeled nearly worldwide. In a study, children's serum was tested for $\operatorname{IgE}$ reactivity to soy, and approximately $0.4 \%$ were found positive [2]. However, literature does not clearly show if there is only a cross-reactivity to soy, coming from peanut or lentil allergy in these patients. Missing challenge studies indicate that allergic patients against soy are rare. Furthermore, there is a high probability that patients reacting against other legumes, like beans and peanut, develop cross-reactivity against soy [1].

Nevertheless, the consumption of soy is rising in Western diets as a result of newly described health and wellness attributes and the desire to consume plant-based protein instead of protein of animal origin. Soy is also an important source of nutrition for infants with milk allergy. Therefore, the potential for accidental intake of soy beans as ingredient or contaminant is increasing for sensitized consumers [3].

Soy bean is valued nutritionally for its high protein content (approx. 35\%) which comprises approx. 10\% albumins and $90 \%$ seed storage globulins. The major proteins are glycinin (Gly m 6) with 40\%, B-conglycinin (Gly $\mathrm{m} \mathrm{5}$ ) with $35 \%$ and $6 \%$ soybean trypsin inhibitor. Besides its high protein content, soy beans are also rich in fat (approx. 20\%) and are widely used in food technology to improve functional properties such as foaming, gelling, or emulsification during processing. Due to the use of same equipment for cereals and soy beans, a contamination with soy is likely in all other crops and need to be checked by the manufacturer.

Ballmer-Weber et al. [4] reported a threshold of $10 \mathrm{mg}$ soy (approx. $4 \mathrm{mg}$ soy protein) per serving size for sensitized consumers. Measurement of such low amounts of soy protein demands an accurate and sensitive method. Besides multiplex real-time PCR methods with a limit of quantification of $8.5 \mathrm{mg} / \mathrm{kg}$ soy beans [5] and commercial PCR systems with a limit of quantification of $0.4 \mathrm{mg} / \mathrm{kg}$ (e.g. Congen Biotechnologie $\mathrm{GmbH}$ Berlin), the only routine method that fulfills all requirements is an ELISA. Scharf et al. [6] reported in 2013 that the analysis of proficiency testing rounds for soy between 2006 and 2011 revealed enormous differences between different commercially available ELISA test kits on the market. The authors discussed that the degree of processing was the main factor to explain these differences which reached in some cases a factor of 200 and more. Recoveries were in nearly all cases not appropriate to state a quantitative result. Furthermore high numbers of false-negative results occurred. This was confirmed by experiments of Gomaa and Boye [7] with differently processed cookies containing soy whereas recoveries even after a short heat treatment were less than $20 \%$ using two 
commercially available test kits in 2013.

The aim of the study was to develop an antibody-based ELISA to quantify soy protein in different types of food samples with special attention to processed and heat-treated samples. The assay should not take longer than one hour from preparation of the sample extract to calculation of results.

\section{Materials and Methods}

\subsection{Test Kit Components}

The sandwich ELISA RIDASCREEN ${ }^{\circledR}$ FAST Soya (R7102; R-Biopharm AG, Darmstadt, Germany) is used for the following validation experiments. It consists of a microtiter plate (48 wells coated with soy-specific monoclonal antibodies), calibrators (corresponding to $0,2.5$, $5.0,10.0$, and $20 \mathrm{mg} / \mathrm{kg}$ soy protein), wash buffer (provided as a 10 -fold concentrate), a soy-specific monoclonal antibody conjugated to peroxidase (provided as an 11-fold concentrate), substrate-chromogen solution, and stop solution. For sample preparation the test kit also contains an Extractor (solution) and an Allergen extraction buffer (provided as a 10 -fold concentrate). Both in combination are necessary to extract soy proteins quantitatively.

\subsection{Extraction of Soy Proteins}

One gram of homogenized sample material is weight into a vial followed by $2.5 \mathrm{~mL}$ of extractor and $17.5 \mathrm{~mL}$ diluted Allergen extraction buffer. In case of a liquid sample only $16.5 \mathrm{~mL}$ of the diluted Allergen extraction buffer are used. The vial is closed and incubated for $10 \mathrm{~min}$ at $100^{\circ} \mathrm{C}$ in a boiling water bath. After cooling down, the vial is centrifuged (at least at $2500 \mathrm{~g}$ for $10 \mathrm{~min}$ ) or the content is filtered. $100 \mu \mathrm{L}$ of the clear supernatant or filtrate is diluted with $400 \mu \mathrm{L}$ diluted Allergen extraction buffer. $100 \mu \mathrm{L}$ of this diluted sample extract are used for the ELISA procedure. If the sample contains tannins and/or polyphenols (e.g. spices, chocolate, wine, nuts, and coffee) $0.25 \%$ casein and $1 \%$ polyvinylpyrrolidon (PVP) are added to the diluted Allergen extraction buffer before using the buffer for extraction of these kinds of samples.

\subsection{ELISA Procedure}

A sufficient number of wells are inserted in the microwell holder. Sample extracts, calibrators, and control sample extracts are pipetted in duplicate on the plate. As the antigen-antibody reaction starts directly after pipetting, only 24 wells (three strips of 8 wells each) should be used. If more wells are required an uncoated pre-plate should be used to pipette all calibrators and sample extracts. The required quick transfer is performed by using an 8-channel pipette. One hundred $\mu \mathrm{L}$ of calibrator solution or sample extract are pipetted in each designated well in duplicate followed by an incubation of $10 \mathrm{~min}$ at room temperature. Afterwards the plate is washed three times using $250 \mu \mathrm{L}$ of the diluted wash buffer for each well. The antibody-peroxidase conjugate concentrate is diluted appropriately and $100 \mu \mathrm{L}$ is pipetted in each well followed by a further $10 \mathrm{~min}$ incubation step. The plate is washed again three times with diluted wash buffer and $100 \mu \mathrm{L}$ of ready-to-use substrate-chromogen solution is added to each well. After incubation at room temperature for $10 \mathrm{~min}$ in the dark, the enzymatic conversion is stopped by adding 100 $\mu \mathrm{L}$ stop solution. Absorption is read at $450 \mathrm{~nm}$. By applying an appropriate calibration curve fitting procedure (e.g. RIDA ${ }^{\mathbb{B}}$ SOFT Win.net, Z9996 from R-Biopharm AG) by cubic spline function, the concentrations of the samples are determined. If samples were diluted as described in chapter 2.2, results for soy protein concentration of each sample can be read directly from the calibration curve since the concentrations of these calibrators already include the standard dilution factor of $1: 100$. If a higher dilution is necessary due to high soy protein concentrations not covered by the calibration function, this further dilution needs to be taken into account when sample concentrations are calculated.

\subsection{Validation}

The validation scheme was according to an AOAC guideline for validation of commercial ELISA test kits to quantify allergens in food [8].

\subsubsection{Selectivity}

The major soy proteins glycinin, $\beta$-conglycinin, and Kunitz soybean trypsin inhibitor are measured in the ELISA system and reactivities are related to the calibrator material which is soy flour with a total protein content of $39 \%$.

Possible cross-reactivities of the antibody-based system are characterized by analyzing possible food components/commodities that may occur together with soy. These components/commodities are extracted and diluted as described in 2.2.

To identify contaminations with soy, the PCR kit SureFood ${ }^{\circledR}$ Allergen ID Soya (R-Biopharm, S3101) was used.

Possible interferants that are known from other validation studies (e.g. polyphenol- and tannin-containing food) were spiked (see 2.4.5.) with known amounts of soy, extracted and analyzed as described (chapter 2.3).

\subsubsection{Limit of Detection}

Three different soy negative food samples (bread bakery mixture, chocolate, and sausage) are used to characterize the limit of detection (LoD). Each food sample (matrix) is extracted ten times and analyzed. Calculation of concentrations for blank samples using the entire calibration function often results in calculated concentrations which do not fit to OD values of samples in correlation to OD values of low concentrated calibrators. Instead, a second order 
polynomial curve fitting for the low concentration calibrators was used to estimate a concentration for each sample. From a mathematical standpoint it can be expected that negative values also occur since a perfect blank is scattered around zero concentration [9]. For each matrix the LoD was calculated as mean plus the threefold standard deviation.

\subsubsection{Limit of Quantification}

Bread bakery mixture and margarine are used to confirm the limit of quantification (LoQ). All matrices and Allergen extraction buffer (see 2.1) are spiked at $2.5 \mathrm{mg} / \mathrm{kg}$ soy protein which is also the concentration of the lowest soy containing calibrator. Ten replicates are analyzed for each matrix and buffer, following the procedures described in 2.2 and 2.3.

\subsubsection{Precision}

During a single-laboratory validation only repeatability and within-lab reproducibility can be characterized. Determination of reproducibility requires data from a collaborative test. For determination of repeatability, six subsamples of two different margarines each spiked at 5 $\mathrm{mg} / \mathrm{kg}$ and $8 \mathrm{mg} / \mathrm{kg}$ were analyzed as described above. For within-lab reproducibility, three different technicians spiked, extracted and analyzed the same set of margarines as described for repeatability but only as duplicates.

\subsubsection{Recovery}

To perform spiking experiments, a defined amount of soy protein needs to be added to the sample. Since only $\mathrm{mg}$ quantities need to be added, this can only be achieved by a spiking solution of soy proteins. For preparation, soy flour with a known protein content (e.g. 40\% determined by Dumas) is suspended at a concentration of $1 \mathrm{mg} / \mathrm{mL}$ soy flour in a buffer containing $360.4 \mathrm{~g} / \mathrm{L}$ urea, $6.8 \mathrm{~g}$ sodium chloride, $1.48 \mathrm{~g}$ disodium hydrogen phosphate, $0.44 \mathrm{~g}$ potassium dihydrogen phosphate, and $1 \mathrm{~g}$ Tween 20 . This suspension contains $0.4 \mathrm{mg} / \mathrm{mL}$ soy protein and is further diluted using the diluted Allergen extraction buffer (see 2.1) $1: 4$ resulting in a concentration of $0.1 \mathrm{mg} / \mathrm{mL}$ soy protein. By pipetting $100 \mu \mathrm{L}$ of this soy protein containing solution to $1 \mathrm{~g}$ sample, the resulting concentration in this sample is $10 \mathrm{mg} / \mathrm{kg}$ soy protein.

Recovery was checked for unprocessed matrices such as bakery mixture, ketchup, margarine, nut nougat cream, and sausage. All matrices were spiked at 2.5, 5.0, 10.0, and 20.0 $\mathrm{mg} / \mathrm{kg}$ soy protein, extracted and analyzed. For analysis of 24 spices and miscellaneous commodities that contain interferants e.g. polyphenols, extraction using casein and PVP was used (see 2.2). Each matrix was spiked at a 10 $\mathrm{mg} / \mathrm{kg}$ soy protein level. Processed samples such as hazelnut cake and minced cooked meat were spiked before processing at levels between $20 \mathrm{mg} / \mathrm{kg}$ and $4000 \mathrm{mg} / \mathrm{kg}$ soy protein. The low levels are produced by depleting the high soy level matrix with blank matrix to the desired concentration.

\subsubsection{Samples from local retailers}

Various samples with and without declaration of soy were collected from the market and analyzed. Since soy is added as an ingredient to some food samples, sometimes very high dilutions before measurement were necessary.

\subsubsection{Robustness}

Under routine conditions, environmental parameters in a laboratory may change to a certain degree. For testing robustness of the ELISA these parameters were checked to an adequate extent. The parameters tested were incubation temperature $\left(18^{\circ} \mathrm{C}, 23^{\circ} \mathrm{C}, 37^{\circ} \mathrm{C}\right)$, ELISA incubation time ( 9 min, $10 \mathrm{~min}, 11 \mathrm{~min})$, and sample/calibrator volume $(90 \mu \mathrm{L}$, $100 \mu \mathrm{L}, 110 \mu \mathrm{L})$.

\subsubsection{Results from Proficiency Tests}

Data of different proficiency test rounds are available. One round (RVEP 150114) was provided by DRRR (Deutsches Referenzbüro für Ringversuche und Referenzmaterialien; http://www.drrr.de/en/) and consisted of 3 different cookie materials (one blank and two contaminated samples). Two rounds (02/2013 and 02/2014) were provided by DLA (Dienstleistung Lebensmittel Analytik GbR; http://www.dla-lvu.de) and consisted in both cases of a bakery product and a boiled sausage. Both provided also an uncontaminated material for the participants. Three rounds $(27130,27147$, and 27165) were provided by FAPAS (Food Analysis Performance Assessment Scheme) and consisted of spiked and unspiked wheat flour.

\section{Results and Discussion}

\subsection{Selectivity}

Related to the calibrator material, Glycinin, $\beta$-Conglycinin, and Kunitz soybean trypsin inhibitor are detected with $408 \%, 7.3 \%$ and $0.5 \%$, respectively. It can be concluded that the ELISA is specific for Glycinin.

No cross-reactivities to the following commodities were observed:

(1) seeds of cereals and pseudocereals:

Wheat (Triticum aestivum), barley (Hordeum vulgaris), rye (Secale cereal), oats (Avena sativa), rice (Oriza sativa), quinoa (Chenopodium quinoa), kamut (Triticum turanicum), amaranth (genus Amaranthus), buckwheat (Fagopyrum esculentum), spelt (Triticum spelta)

(2) seeds of trees:

Apricot (Prunus armeniaca), chestnut (genus Castanea), cashew (Anacardium occidentale), almond (Prunus dulcis), macadamia (Macadamia ssp.), pecan (Carya illinoinensis), coconut (Cocos nucifera), pistachio (Pistacia vera), brazilnut (Bertholletia excels), hazelnut (Corylus avellana), pine (genus Pinus)

(3) seeds of other plants:

Sunflower (Helianthus annuus), pumpkin (Curcubita 
pepo), poppy (genus Papaver), flax (Linum usitatissimum), canola (Brassica napus)

(4) spices:

Yellow mustard seeds (Sinapis alba), black mustard seeds (Brassica nigra), celery leafs (Apium graveolens), celery seeds (Apium graveolens), celery root powder (Apium graveolens), fennel seed (Foeniculum vulgare), anise seed (Pimpinella anisum), caraway (Carum carvi), cumin (Cuminum cyminum), black caraway (Nigella sativa), curcuma (Curcuma zedoaria), onion (Allium cepa), black pepper (Piper nigrum), white pepper (Piper nigrum), chili pepper (genus Capsicum), bell pepper (genus Capsicum), cloves (Syzygium aromaticum), cinnamon (Cinnamomum zeylanicum), savory (Satureja hortensis), basil (Ocimum basilicum), marjoram (Origanum majorana), ginger (Zingiber officinale), nutmeg (Myristica fragrans), cardamom (Amomum subulatum)

(5) other commodities:

Bovine gelatin, porcine gelatin, fish gelatin, skim milk powder, egg lecithin, soy oil (Glycine max), apricot kernel oil, red wine, white wine, kiwifruit (Actinidia deliciosa), cocoa (Theobroma cacao), bovine serum albumin, ovalbumin, fetal calf serum, whole egg powder, roasted coffee (Coffea arabica), margarine, ketchup, sugar.

Botanically, soy belongs to the Fabaceae family also known as Leguminoseae family which also contains some other important edible plants such as lentils, beans, and peas. Therefore these commodities are characterized separated from all other commodities. To avoid confusion only botanical names are given. No cross-reactivities were observered to Lupinus angustifolius, Lupinus albus and Lupinus luteus. In contrast, cross-reactivities were observed against Pisum sativum (dried and fresh seeds), Vicia pannonica, Lens culinaris, Arachis hypogea (roasted and raw), Cicer arietinum, Trigonella foenum-graecum, Trifolium pratense, Phaseolus vulgaris, Phaseolus lunatus, Vicia faba, Phaseolus coccineus, Vigna radiate and Vigna angularis. This was expected since soy is closely related to other members of Fabaceae but from a security standpoint for customers this fact is positive. Many customers sensitized to soy are cross-reacting with these Fabaceae members [1].

During development of the ELISA it was recognized that polyphenol- and tannin-containing commodities will disturb the immunochemical reaction. Therefore, a special extraction using casein and PVP was developed. Results using this extraction are show in table 1. Except celery (not shown), all spiked materials were detected positive and most of them showed recovery rates of more than $50 \%$ which is acceptable for difficult matrices. For diluted extracts of spices (1:10), the recovery will increase (data not shown). This is often described for antibody-based ELISA systems, because polyphenols strongly interact with proteins and are able to precipitate them efficiently [10].
Table 1. Different commodities extracted in the presence of $0.25 \%$ casein and 1\% PVP to avoid interferences; in parallel the sample extracts were spiked at $10 \mathrm{mg} / \mathrm{kg}$ soy protein to verify that the interferences were suppressed in most samples

\begin{tabular}{|c|c|c|c|}
\hline commodity & $\begin{array}{l}\text { blank } \\
\text { (OD) }\end{array}$ & $\begin{array}{c}\text { spike } \\
(\mathrm{mg} / \mathrm{kg})\end{array}$ & $\begin{array}{l}\text { recovery } \\
\quad(\%)\end{array}$ \\
\hline anise & 0.076 & 7.5 & 75 \\
\hline basil & 0.061 & 4.5 & 45 \\
\hline caraway & 0.061 & 8.7 & 87 \\
\hline black caraway & 0.074 & 5.8 & 58 \\
\hline cardamom & 0.076 & 5.8 & 58 \\
\hline celery root powder & 0.069 & 10.6 & 106 \\
\hline chili & 0.053 & 11.0 & 110 \\
\hline chocolate & 0.074 & 8.2 & 82 \\
\hline cinnamon & 0.060 & 3.2 & 32 \\
\hline cocoa & 0.065 & 3.4 & 34 \\
\hline $\begin{array}{c}\text { Coriander } \\
\text { (Coriandrum sativum) }\end{array}$ & 0.069 & 7.5 & 75 \\
\hline curcuma & 0.063 & 2.8 & 28 \\
\hline fennel seed & 0.068 & 9.7 & 97 \\
\hline ginger & 0.065 & 3.0 & 30 \\
\hline marjoram & 0.072 & 5.7 & 57 \\
\hline $\begin{array}{c}\text { brown mustard } \\
\text { (Brassica juncea) }\end{array}$ & 0.089 & 12.4 & 124 \\
\hline nutmeg & 0.051 & 5.4 & 54 \\
\hline red wine & 0.071 & 10.3 & 103 \\
\hline roasted coffee & 0.170 & 10.1 & 101 \\
\hline savory & 0.060 & 3.1 & 31 \\
\hline sweet paprika & 0.065 & 7.1 & 71 \\
\hline Walnut (Juglans regia) & 0.059 & 9.9 & 99 \\
\hline white pepper & 0.108 & 7.6 & 76 \\
\hline
\end{tabular}

\subsection{Limit of Detection}

Results for the estimation of LoD in bread bakery mixture, chocolate and sausage are presented in table 2 and revealed values of $0.32,0.15$ and $0.23 \mathrm{mg} / \mathrm{kg}$ soy protein. The extrapolated concentrations are close to zero and it can therefore be concluded that none of these three matrices have a background effect on the signal. We recommend a possible user of this test kit to verify these LoD values for any unknown matrix as recommended by Koerner et al. [11] for gluten analysis since the matrix may influence the measured signal.

Table 2. Matrix-specific estimation of limit of detection in bread bakery mixture, chocolate, and sausage; Optical densities (OD) values of the zero calibrator are given as reference while mean and standard deviations (SD) in $\mathrm{mg} / \mathrm{kg}$ are used for calculation the LoD

\begin{tabular}{|c|c|c|c|c|c|}
\hline matrix & $\begin{array}{c}\text { calibrator 1 } \\
(\mathrm{OD})\end{array}$ & $\begin{array}{c}\text { mean } \\
(\mathrm{OD})\end{array}$ & $\begin{array}{c}\text { mean } \\
(\mathrm{mg} / \mathrm{kg})\end{array}$ & $\begin{array}{c}\mathrm{SD} \\
(\mathrm{mg} / \mathrm{kg})\end{array}$ & $\begin{array}{c}\text { mean }+ \\
3 \times \mathrm{SD} \\
(\mathrm{mg} / \mathrm{kg})\end{array}$ \\
\hline $\begin{array}{c}\text { bread } \\
\text { bakery } \\
\text { mixture }\end{array}$ & 0.061 & 0.078 & 0.16 & 0.055 & 0.32 \\
\hline chocolate & 0.058 & 0.071 & 0.04 & 0.039 & 0.15 \\
\hline sausage & 0.065 & 0.071 & 0.11 & 0.036 & 0.23 \\
\hline
\end{tabular}

\subsection{Limit of Quantification}

Results for the confirmation of a LoQ of $2.5 \mathrm{mg} / \mathrm{kg}$ soy protein in bread bakery mixture and margarine are presented in table 3 . They revealed for both matrices that 
precision at this low concentration is comparable to values of soy proteins in buffer. The recovery is $100 \%$ for margarine and $116 \%$ for the bread bakery mixture. This procedure to confirm a claimed LoQ is by far the most suitable way to handle this validation parameter but is still not included in the most recent validation guidelines [12].

Table 3. Matrix-specific confirmation of the limit of quantification in bread bakery mixture, chocolate, and buffer compared to the calibrator with a concentration of $2.5 \mathrm{mg} / \mathrm{kg}$ soy protein; standard deviations (SD) in $\mathrm{mg} / \mathrm{kg}$ and coefficient of variation $(\mathrm{CV})$ in percent are used to confirm the LoQ together with the measured concentration which give a measure of recovery at a concentration at or near the LoQ

\begin{tabular}{|c|c|c|c|}
\hline matrix & $\begin{array}{c}\text { observed } \\
(\mathrm{mg} / \mathrm{kg})\end{array}$ & $\begin{array}{c}\mathrm{SD} \\
(\mathrm{mg} / \mathrm{kg})\end{array}$ & $\begin{array}{c}\mathrm{CV} \\
(\%)\end{array}$ \\
\hline $\begin{array}{c}\text { calibrator } 2.5 \\
\mathrm{mg} / \mathrm{kg}\end{array}$ & - & 0.042 & 1.7 \\
\hline $\begin{array}{c}\text { bread bakery } \\
\text { mixture }\end{array}$ & 2.9 & 0.106 & 3.6 \\
\hline margarine & 2.5 & 0.094 & 3.7 \\
\hline buffer & 2.7 & 0.130 & 4.8 \\
\hline
\end{tabular}

\subsection{Precision}

Characterization of repeatability is presented in table 4 for calibrators and samples. It was observed that all $\mathrm{CV}$ values for $\mathrm{OD}$ values and concentrations were in an acceptable range between 2.0 and $5.3 \%$. Due to the very low OD readings for the zero calibrators, a $\mathrm{CV}$ of $8.7 \%$ is still in the expected range.

As expected, CVs for within-lab reproducibility increased slightly since three persons on different days were involved (table 5). Nevertheless, CVs around $6.5 \%$ are very good. These results will differ if more persons with different stages of knowledge and training are involved (see Results from Proficiency Tests, table 10.). Acceptable values for repeatability should not exceed values stated in AOAC Appendix K [13]. According to this guidance a sample with a soy protein concentration around $10 \mathrm{mg} / \mathrm{kg}$ should not be analyzed with a repeatability of more than $6 \%$. For reproducibility, not more than $11 \%$ are allowed for a sample in this concentration range. It is clear, that all CVs are lower than these threshold values.

Table 4. Evaluation of repeatability standard deviation in calibrators and different matrices $(n=6)$

\begin{tabular}{|c|c|c|c|}
\hline calibrators & mean & SD & CV \\
\hline & OD & OD & $\%$ \\
\hline $0.0 \mathrm{mg} / \mathrm{kg}$ & 0.067 & 0.006 & 8.7 \\
\hline $2.5 \mathrm{mg} / \mathrm{kg}$ & 0.306 & 0.007 & 2.1 \\
\hline $5.0 \mathrm{mg} / \mathrm{kg}$ & 0.551 & 0.027 & 5.0 \\
\hline $10.0 \mathrm{mg} / \mathrm{kg}$ & 1.021 & 0.053 & 5.2 \\
\hline $20.0 \mathrm{mg} / \mathrm{kg}$ & 1.830 & 0.039 & 2.1 \\
\hline samples & OD & OD & $\%$ \\
\hline margarine 1 & 0.513 & 0.023 & 4.4 \\
\hline margarine 2 & 0.877 & 0.017 & 2.0 \\
\hline cookie & 0.127 & 0.006 & 4.4 \\
\hline samples & $\mathrm{mg} / \mathrm{kg}$ & $\mathrm{mg} / \mathrm{kg}$ & $\%$ \\
\hline margarine 1 & 4.6 & 0.24 & 5.3 \\
\hline margarine 2 & 8.5 & 0.18 & 2.1 \\
\hline
\end{tabular}

Table 5. Characterization of within-lab reproducibility standard deviation using data from three different persons, on different days with identical sample materials

\begin{tabular}{|c|c|c|c|c|c|c|c|c|c|}
\hline \multirow[b]{2}{*}{ calibrator } & \multicolumn{2}{|c|}{ analyst 1} & \multicolumn{2}{|c|}{ analyst 2} & \multicolumn{2}{|c|}{ analyst 3} & \multirow[b]{2}{*}{ mean } & \multirow[b]{2}{*}{ SD } & \multirow[b]{2}{*}{$\mathrm{CV}$} \\
\hline & rep.1 & rep. 2 & rep. 1 & rep. 2 & rep. 1 & rep. 2 & & & \\
\hline & OD & OD & OD & OD & OD & OD & OD & OD & $\%$ \\
\hline $0.0 \mathrm{mg} / \mathrm{kg}$ & 0.061 & 0.059 & 0.046 & 0.048 & 0.055 & 0.047 & 0.053 & 0.007 & 12.4 \\
\hline $2.5 \mathrm{mg} / \mathrm{kg}$ & 0.287 & 0.262 & 0.237 & 0.229 & 0.318 & 0.318 & 0.275 & 0.039 & 14.1 \\
\hline $5.0 \mathrm{mg} / \mathrm{kg}$ & 0.563 & 0.494 & 0.456 & 0.458 & 0.533 & 0.520 & 0.504 & 0.043 & 8.5 \\
\hline $10.0 \mathrm{mg} / \mathrm{kg}$ & 1.075 & 0.949 & 0.963 & 0.880 & 0.974 & 1.006 & 0.975 & 0.065 & 6.6 \\
\hline $20.0 \mathrm{mg} / \mathrm{kg}$ & 1.885 & 1.708 & 1.705 & 1.715 & 1.776 & 1.765 & 1.759 & 0.069 & 3.9 \\
\hline samples & & & & & & & & & \\
\hline margarine 1 & 0.545 & 0.484 & 0.464 & 0.402 & 0.491 & 0.507 & 0.482 & 0.048 & 9.9 \\
\hline margarine 2 & 0.787 & 0.794 & 0.766 & 0.738 & 0.834 & 0.911 & 0.805 & 0.061 & 7.6 \\
\hline cookie & 0.077 & 0.074 & 0.085 & 0.078 & 0.109 & 0.113 & 0.089 & 0.017 & 19.3 \\
\hline & $\mathrm{mg} / \mathrm{kg}$ & $\mathrm{mg} / \mathrm{kg}$ & $\mathrm{mg} / \mathrm{kg}$ & $\mathrm{mg} / \mathrm{kg}$ & $\mathrm{mg} / \mathrm{kg}$ & $\mathrm{mg} / \mathrm{kg}$ & $\mathrm{mg} / \mathrm{kg}$ & $\mathrm{mg} / \mathrm{kg}$ & \\
\hline margarine 1 & 5.2 & 4.6 & 5.1 & 4.4 & 4.6 & 4.8 & 4.7 & 0.31 & 6.5 \\
\hline margarine 2 & 7.7 & 7.7 & 8.3 & 8.0 & 8.3 & 9.1 & 8.2 & 0.54 & 6.6 \\
\hline cookie & $<\mathrm{LOQ}$ & $<\mathrm{LOQ}$ & $<\mathrm{LOQ}$ & $<\mathrm{LOQ}$ & $<$ LOQ & $<\mathrm{LOQ}$ & & & \\
\hline
\end{tabular}




\subsection{Recovery}

The characterization of recovery is described in table 6 for spiked samples and in table 7 for incurred (processed) samples. Five different types of matrices were spiked at different levels, extracted and analyzed. As can be seen in table 6 , the range of recovery varies from 86 to $127 \%$ irrespectively of the concentration and matrix. The spiked buffer control is also included to show that the spiking solution was produced correctly.

Results for processed matrices in comparison to unprocessed original material are shown in table 7. For hazelnut cake, recoveries decrease slightly with increasing temperature and time but are still acceptable for this high degree of processing. In contrast, roasting of minced meat does not affect recoveries. Differences between different spiking levels are more pronounced than differences between raw and roasted materials. According the AOAC Appendix K [13], acceptable levels of recovery for sample with soy protein concentrations around $10 \mathrm{mg} / \mathrm{kg}$ should be between 80 and $115 \%$. These levels were nearly always obtained for spiked samples with exception of only a few cases (table 6). Abbott et al. [14] recommended recoveries between 50 and $150 \%$ for highly processed samples containing incurred allergens as analyte. As can be seen in table 7 , recoveries for highly processed cookies and meat are acceptable due to the recommendations stated above. In contrast to other commercially available ELISA systems $[6,7]$, the ELISA RIDASCREEN®FAST Soya is suitable for quantification of soy proteins in even strongly heated food.

Table 6. Recoveries of different matrices spiked at four different concentration levels

\begin{tabular}{|c|c|c|c|}
\hline matrix & spike $(\mathrm{mg} / \mathrm{kg})$ & measured $(\mathrm{mg} / \mathrm{kg})$ & recovery (\%) \\
\hline \multirow{4}{*}{$\begin{array}{l}\text { hazelnut } \\
\text { cocoa } \\
\text { spread }\end{array}$} & 2.5 & 2.3 & 92 \\
\hline & 5 & 4.3 & 86 \\
\hline & 10 & 9.0 & 90 \\
\hline & 20 & 18.0 & 90 \\
\hline \multirow{4}{*}{$\begin{array}{c}\text { cake } \\
\text { bakery mix }\end{array}$} & 2.5 & 2.7 & 109 \\
\hline & 5 & 5.4 & 109 \\
\hline & 10 & 11.7 & 117 \\
\hline & 20 & 23.0 & 115 \\
\hline \multirow{4}{*}{ margarine } & 2.5 & 2.3 & 92 \\
\hline & 5 & 4.6 & 92 \\
\hline & 10 & 9.6 & 96 \\
\hline & 20 & 19.1 & 95 \\
\hline \multirow{4}{*}{ sausage } & 2.5 & 2.2 & 86 \\
\hline & 5 & 4.7 & 94 \\
\hline & 10 & 9.1 & 91 \\
\hline & 20 & 19.4 & 97 \\
\hline \multirow{4}{*}{ ketchup } & 2.5 & 2.5 & 100 \\
\hline & 5 & 5.1 & 102 \\
\hline & 10 & 10.0 & 100 \\
\hline & 20 & 24.2 & 121 \\
\hline \multirow{4}{*}{$\begin{array}{l}\text { control } \\
\text { (buffer) }\end{array}$} & 2.5 & 2.2 & 90 \\
\hline & 5 & 4.6 & 92 \\
\hline & 10 & 9.2 & 92 \\
\hline & 20 & 18.2 & 91 \\
\hline
\end{tabular}

Table 7. Recoveries of different incurred matrices spiked before processing with different amounts of soy flour; for heat-processed minced meat a loss of water of $50 \%$ was assumed

\begin{tabular}{|c|c|c|c|c|}
\hline matrix & $\begin{array}{l}\text { soy flour } \\
(\mathrm{mg} / \mathrm{kg})\end{array}$ & $\begin{array}{l}\text { incurred } \\
(\mathrm{mg} / \mathrm{kg})\end{array}$ & $\begin{array}{c}\text { measured } \\
(\mathrm{mg} / \mathrm{kg})\end{array}$ & $\begin{array}{c}\text { recovery } \\
(\%)\end{array}$ \\
\hline $\begin{array}{c}\text { hazelnut cake } \\
\text { dough }\end{array}$ & 10 & 4000 & 3255 & 81 \\
\hline $\begin{array}{c}\text { hazelnut cake } 10 \\
\text { min at } 200^{\circ} \mathrm{C}\end{array}$ & 10 & 4000 & 2138 & 53 \\
\hline $\begin{array}{c}\text { hazelnut cake } 8 \mathrm{~min} \\
\text { at } 200^{\circ} \mathrm{C}\end{array}$ & 10 & 4000 & 2745 & 69 \\
\hline $\begin{array}{c}\text { hazelnut cake } 15 \\
\text { min at } 180^{\circ} \mathrm{C}\end{array}$ & 10 & 4000 & 2132 & 53 \\
\hline $\begin{array}{c}\text { hazelnut cake } 10 \\
\text { min at } 180^{\circ} \mathrm{C}\end{array}$ & 10 & 4000 & 2419 & 60 \\
\hline $\begin{array}{c}\text { hazelnut cake } 20 \\
\text { min at } 150^{\circ} \mathrm{C} \\
\end{array}$ & 10 & 4000 & 2820 & 70 \\
\hline $\begin{array}{c}\text { hazelnut cake } 15 \\
\text { min at } 150^{\circ} \mathrm{C}\end{array}$ & 10 & 4000 & 2530 & 63 \\
\hline $\begin{array}{c}\text { hazelnut cake } 10 \\
\text { min at } 150^{\circ} \mathrm{C}\end{array}$ & 10 & 4000 & 2801 & 70 \\
\hline minced meat, raw & 10 & 4000 & 3891 & 97 \\
\hline minced meat, raw & 10 & 4000 & 3326 & 83 \\
\hline minced meat, raw & 10 & 4000 & 4506 & 113 \\
\hline minced meat, raw & 1 & 400 & 350 & 88 \\
\hline minced meat, raw & 1 & 400 & 372 & 93 \\
\hline minced meat, raw & 1 & 400 & 377 & 94 \\
\hline minced meat, raw & 0.05 & 20 & 22.0 & 110 \\
\hline minced meat, raw & 0.05 & 20 & 24.3 & 121 \\
\hline minced meat, raw & 0.05 & 20 & 25.0 & 125 \\
\hline $\begin{array}{c}\text { minced meat, } \\
\text { roasted }\end{array}$ & 10 & 8000 & 9261 & 116 \\
\hline $\begin{array}{l}\text { minced meat, } \\
\text { roasted }\end{array}$ & 10 & 8000 & 8323 & 104 \\
\hline $\begin{array}{l}\text { minced meat, } \\
\text { roasted }\end{array}$ & 10 & 8000 & 8977 & 112 \\
\hline $\begin{array}{c}\text { minced meat, } \\
\text { roasted }\end{array}$ & 1 & 800 & 671 & 84 \\
\hline $\begin{array}{l}\text { minced meat, } \\
\text { roasted }\end{array}$ & 1 & 800 & 725 & 91 \\
\hline $\begin{array}{l}\text { minced meat, } \\
\text { roasted }\end{array}$ & 1 & 800 & 703 & 88 \\
\hline $\begin{array}{c}\text { minced meat, } \\
\text { roasted }\end{array}$ & 0.05 & 40 & 45.4 & 113 \\
\hline $\begin{array}{c}\text { minced meat, } \\
\text { roasted }\end{array}$ & 0.05 & 40 & 44.3 & 111 \\
\hline $\begin{array}{l}\text { minced meat, } \\
\text { roasted }\end{array}$ & 0.5 & 40 & 44.6 & 111 \\
\hline
\end{tabular}

\subsection{Samples from Local Retailers}

23 different samples were analyzed (table 8.). Twelve of these samples were not labeled with "may contain soy". These samples were tested well below the LoQ of 2.5 $\mathrm{mg} / \mathrm{kg}$ soy protein. The remaining 11 samples were labeled with "contain soy", nine of them contained soy at sometimes very high concentrations which is only due to the fact that soy was added as ingredient. In two samples soy was added as soy lecithin but not found above LoQ. 
Table 8. Results for different samples from local retailers with and without declaration of soy on the label.

\begin{tabular}{|c|c|c|c|}
\hline commodity & $\begin{array}{l}\text { dilution } \\
\text { factor }\end{array}$ & $\begin{array}{c}\text { soy } \\
\text { declared }\end{array}$ & $\begin{array}{c}\text { concentration } \\
(\mathrm{mg} / \mathrm{kg})\end{array}$ \\
\hline almond cookies & 1 & No & $<$ LoQ \\
\hline biscuit & 1 & No & $<$ LoQ \\
\hline bread & 1 & No & $<$ LoQ \\
\hline cracker & 1 & No & $<\mathrm{LoQ}$ \\
\hline egg noodles & 1 & No & $<$ LoQ \\
\hline flatbread with lupine & 1 & No & $<$ LoQ \\
\hline ham sausage & 1 & No & $<$ LoQ \\
\hline $\begin{array}{l}\text { hypoallergenic baby } \\
\text { food }\end{array}$ & 1 & No & $<$ LoQ \\
\hline liver sausage & 1 & No & $<$ LoQ \\
\hline maize snack & 1 & No & $<$ LoQ \\
\hline grilled sausage & 1 & No & $<$ LoQ \\
\hline semolina pudding & 1 & No & $<$ LoQ \\
\hline chocolate & 200 & Yes & 822 \\
\hline chocolate chip cookies & 2000 & Yes & 16009 \\
\hline chocolate cookies & 200 & Yes & 1914 \\
\hline crème waffle & 2000 & Yes & 21371 \\
\hline digestive biscuits & 2000 & Yes & 10916 \\
\hline infant food & 2000 & Yes & 15521 \\
\hline infant food & 200 & Yes & 2946 \\
\hline noodles & 1 & Yes & 7.1 \\
\hline shortbread biscuits & 2000 & Yes & 10916 \\
\hline margarine with starch & 1 & Yes & $<$ LoQ \\
\hline plant crème & 1 & Yes & $<$ LoQ \\
\hline
\end{tabular}

Table 9. Robustness of the ELISA system; variation of incubation time after adding the sample, different sample and calibrator volumes, and different incubation temperatures; a bakery mix sample with a spiked amount of $5 \mathrm{mg} / \mathrm{kg}$ soy protein was used

\begin{tabular}{|c|c|c|}
\hline condition & mean $(\mathrm{mg} / \mathrm{kg})$ & $\mathrm{SD}(\mathrm{mg} / \mathrm{kg})$ \\
\hline incubation $9 \mathrm{~min}$ & 4.8 & 0.3 \\
\hline incubation $10 \mathrm{~min}$ & 5.0 & 0.3 \\
\hline inbuation $11 \mathrm{~min}$ & 4.5 & 0.3 \\
\hline volume $90 \mu \mathrm{L}$ & 4.5 & 0.4 \\
\hline volume $100 \mu \mathrm{L}$ & 5.0 & 0.3 \\
\hline volume $110 \mu \mathrm{L}$ & 4.6 & 0.4 \\
\hline temperature $18^{\circ} \mathrm{C}$ & 4.9 & 0.3 \\
\hline temperature $23^{\circ} \mathrm{C}$ & 5.0 & 0.3 \\
\hline temperature $37^{\circ} \mathrm{C}$ & 4.3 & 0.3 \\
\hline
\end{tabular}

\subsection{Robustness}

Table 9 shows the results of robustness experiments. A bakery cake mix containing $5 \mathrm{mg} / \mathrm{kg}$ soy protein was used in $n=10$. All standard deviations were comparable and all mean concentrations were in an acceptable range from 4.3 to $5.0 \mathrm{mg} / \mathrm{kg}$. One significant difference was observed when comparing the results for the $37^{\circ} \mathrm{C}$ incubation step with the results at $18^{\circ} \mathrm{C}$ and $23^{\circ} \mathrm{C}$. It can be concluded that increasing the incubation temperature higher than $23^{\circ} \mathrm{C}$ may result in slightly lower concentration values.

\subsection{Results from Proficiency Tests}

Results from seven different PT rounds are presented in table 10. For FAPAS round 27130 one outlier was eliminated due to a fourfold higher concentration value. This can normally be explained by contamination in the participating laboratory or inhomogeneity of the PT sample. Same is true for FAPAS round 27165 where one outlier was eliminated due to a fourfold higher concentration. As can be clearly seen in table 10 , the RIDASCREEN ${ }^{\circledR}$ FAST Soya ELISA shows acceptable or even better relative reproducibility standard deviations between 15 and $38 \%$ within a concentration range of 4.1 up to $167.5 \mathrm{mg} / \mathrm{kg}$ soy protein. This is the normal range where a typical reproducibility standard deviation is expected when several analysts use a commercial ELISA test kit under slightly differing conditions (that does also include different stages of training and knowledge). These high values seem to be in contrast to recommendations given by AOAC [14] but it should be remembered that nearly all commercial allergen assays that are available on the market include a dilution step of the sample before measurement due to the extraction procedure. Therefore, the concentration of the extracted solution should be taken as a basis for comparison and not the concentration of the allergen in the sample [15]. For a concentration of $1 \mathrm{mg} / \mathrm{L}$ we could expect an $\mathrm{RSD}_{\mathrm{R}}$ of $16 \%$ referring to [14]. Compared to this, the lowest calibrator in the ELISA system described in this publication is 0.025 $\mathrm{mg} / \mathrm{L}$.

One blank material was tested for DRRR round RVEP 150114 and 8 out of 9 labs delivered a qualitative correct result. This single lab found a soy contamination at a level of $4.7 \mathrm{mg} / \mathrm{kg}$ soy protein. It should be remembered that the LoQ of this method is at $2.5 \mathrm{mg} / \mathrm{kg}$. All participants of the DLA rounds (6 or 8 participants) and FAPAS rounds 27130 and 27147 (16 or 19 participants) found blank samples as expected below the LoQ or even LoD (data not shown). Only for FAPAS round 27165 one participant out of 24 participants reported a false positive result. 
Table 10. Results from seven different proficiency testing rounds provided by DRRR, DLA and FAPAS

\begin{tabular}{|c|c|c|c|c|c|c|}
\hline PT provider & PT round & matrix & $\begin{array}{c}\text { participants } \\
(\mathrm{n})\end{array}$ & $\begin{array}{c}\text { mean } \\
(\mathrm{mg} / \mathrm{kg})\end{array}$ & $\begin{array}{c}\text { SD } \\
(\mathrm{mg} / \mathrm{kg})\end{array}$ & $\begin{array}{c}\text { CV } \\
(\%)\end{array}$ \\
\hline DRRR & RVEP 150114 & cookie & 5 & 10.3 & 1.4 & 34 \\
\hline DRRR & RVEP 150114 & cookie & 5 & 167.5 & 46.9 & 15 \\
\hline DLA & $02 / 2014$ & cake mix & 8 & 24.2 & 6.7 & 28 \\
\hline DLA & $02 / 2013$ & cookie & 6 & 16.8 & 6.4 & 38 \\
\hline FAPAS & 27130 & wheat flour & 19 & 13.2 & 4.4 & 33 \\
\hline FAPAS & 27147 & wheat flour & 16 & 32.7 & 11.7 & 36 \\
\hline FAPAS & 27165 & wheat flour & 22 & & & \\
\hline
\end{tabular}

\section{Conclusions}

The data presented, clearly show that the sandwich ELISA RIDASCREEN ${ }^{\circledR}$ FAST Soya can be used for a reliable detection and quantification of soy in food. Besides high recoveries from even highly processed samples, precision values within laboratory were excellent. Data analysis of different proficiency test rounds revealed that even outside the method developer's laboratory, users were able to produce precise results. One might argue that several cross-reactivities against other members of the Fabaceae family exist and that this narrows the possible areas of use. It should be kept in mind that consumers sensitized to soy also show reactions to those cross-reacting members of the Fabaceae family. From a theoretical point of view, a more selective monoclonal antibody system is possible, but a high selectivity could result in the loss of detection of soy varieties which is much more severe than detecting some plants belonging to the Fabacea family. To clearly identify only soy, real-time PCR is a good possibility to confirm positive results from an ELISA in a qualitative way. Especially during characterization of selectivity, a lot of non-cross-reacting commodities were tested positive at the beginning. Real-time PCR was used to confirm a soy contamination. This clearly shows that during storage, food processing and maybe packaging, soy contaminations are quite regular. This will help sensitized consumers to identify harmful foods but also to obtain suitable food.

At the moment the RIDASCREEN ${ }^{\circledR}$ FAST Soya ELISA is the only ELISA that quantitates soy in processed food matrices using a quick and easy extraction procedure.

\section{Acknowledgements}

R-Biopharm would like to thank RIKILT as the source of the Cell Lines and monoclonal antibodies. Furthermore we would like to thank Ms. Patricia Meinhardt (Washington, MO, United States of America) for proof-reading the manuscript.

\section{REFERENCES}

[1] A. K. Verma, S. Kumar, M. Das, P. D. Dwivedi. A Comprehensive Review of Legume Allergy. Clinic. Rev. Allerg. Immunol., Vol.45, 30-46, 2013.

[2] S. H. Sicherer, H. A. Simpson. Food Allergy. J. Allergy Clin Immunol Vol.117 (2 suppl Mini-Primer), S470-S475, 2006.

[3] H. Saeed, C. Gagnon, E. Cober, S. Gleddie. Using patient serum to epitope map soybean glycinins reveals common epitopes shared with many legumes and tree nuts, Mol Immunol., Vol.70, 125-133, 2016.

[4] B. K. Ballmer-Weber, S. Vieths. Soy allergy in perspective, Curr Opinion Allergy Clin Immunol., Vol.8, No.3, 270-275, 2008.

[5] F. Luber, A. Demmel, K. Pankofer, U. Busch, K. H. Engel. Simultaneous quantification of the food allergens soy bean, celery, white mustard and brown mustard via combination of tetraplex real-time PCR and standard addition, Food Control, Vol.47, 246-253, 2015.

[6] A. Scharf, U. Kassel, G. Wichmann, M. Besler. Performance of ELISA and PCR methods for the determination of allergens in food: An evaluation of six years of proficiency testing for soya (Glycine max L.) and wheat gluten (Triticum aestivum L.), J. Agric. Food Chem. Vol. 61, No.43, 10261-10272, 2013.

[7] A. Gomaa, J. I. Boye. Impact of thermal processing time and cookie size on the detection of casein, egg, gluten and soy allergens in food, Food Res. Internat., Vol. 52, 483-489, 2013.

[8] M. Abbott, S. Hayward, W. Ross, S. B. Godefroy, F. Ulberth, A. J. van Hengel, J. Roberts, H. Akiyama, B. Popping, J. M. Yeung, P. Wehling, S. L. Taylor, R. E. Poms, P. Delahaut, Validation Procedures for Quantitative Food Allergen ELISA Methods: Community Guidance and Best Practices, J. AOAC Internat. Vol. 93: 442-450, 2010.

[9] P. Koehler, T. Schwalb, U. Immer, M. Lacorn, P. Wehling, C. Don C. AACCI Approved Methods Technical Committee Report: Collaborative Study on the Immunochemical Determination of Intact gluten Using an R5 Sandwich ELISA, Cereal Foods World, Vol.58, No. 1, 36-40, 2013.

[10] M. Lacorn, C. Gößwein, U. Immer. Determination of residual egg white proteins in red wines during and after fining, Am. J. Enol. Vitic., Vol. 62, 382-385, 2011.

[11] T. B. Koerner, M. Abbott, S. B. Godefroy, B. Poepping, J. M. Yeung, C. Diaz-Amigo, J. Roberts, S. L. Taylor, J. L. Baumert, F. Ulberth, P. Wehling, P. Koehler. Validation Procedures for Quantitative Gluten ELISA Methods: AOAC Allergen Community Guidance and Best Practices, J. AOAC 
Internat. Vol. 96, No. 5, 1033-1040, 2013.

[12] B. Magnusson, U. Örnemark, (eds.) Eurachem Guide: The fitness for Purpose of Analytical Methods - A Laboratory Guide to Method Validation and Related Topics, 2nd ed., 2014, available online at www.eurachem.org

[13] AOAC Official Methods of Analysis (2013) Appendix K: Guidelines for Dietary Supplements and Botanicals. Part I. AOAC Guidelines for Singel-Laboratory Validation of Chemical Methods for Dietary Supplements and Botanicals.
[14] M. Abbott, S. Hayward, W. Ross, S. B. Godefroy, F. Ulberth, A. J. van Hengel, J. Roberts, H. Akiyama, B. Popping, J. M. Yeung, P. Wehling, S. L. Taylor, R. E. Poms, P. Delahaut. Validation Procedures for Quantitative Food Allergen ELISA Methods: Community Guidance and Best Practices, J. AOAC Internat. Vol. 93, 442-450, 2010.

[15] M. Lacorn, R. Ristow, T. Weiss, U. Immer. Collaborative Tests of ELISA Methods for the Determination of Egg White Proteins and Caseins Used as Fining Agents in Red and White Wines, Food Anal. Meth., Vol. 7, 417-429, 2014.

\footnotetext{
${ }^{\text {i }}$ Dedicated to Ulrike Immer for her pioneer work in allergen analysis
} 